\title{
Pengetahuan Personal Hygiene Remaja Putri pada Kasus Keputihan
}

\author{
Helmy Ilmiawati, Kuntoro \\ Departemen Biostatistika dan Kependudukan FKM UNAIR \\ Fakultas Kesehatan Masyarakat Universitas Airlangga \\ Jl.Mulyorejo Kampus C Unair Surabaya 601115 \\ Alamat Korespondensi: \\ Helmy Ilmiawati \\ Email: mee.midwife@gmail.com
}

\begin{abstract}
This study was a cross sectional study. This research was conducted at the Institute of Islamic Education Nurul Haromain "SMP Plus Fityani" Ngroto village Pujon Malang. The purpose of this study to determine how personal hygiene knowledge of young women with vaginal discharge cases experienced. Researchers used 50 respondents and all met the inclusion criteria. Sampling method was used total sampling. The variables studied were respondent characteristics include age and educational level. While the variable knowledge of personal hygiene includes washing hands before touching the genitals, vagina washing the right way, the use of underwear, the use of pantyliener. For the case of white discharge is white discharge experienced by respondents. All variables were measured using the enclosed questionnaire and analyzed using descriptive analysis. The results most of the characteristics of the age of respondents was 13 years old. The results of the knowledge of personal hygiene mostly young girls who do not have a good knowledge of 23 respondents (46\%) of personal hygiene. For the case of white discharge experienced by most experienced white discharge was abnormal discharge in the amount of 27 respondents (54\%). Knowledge wasn't good due to limited access to information and a facilitator at the Education Institute. If left unchecked it will cause serious reproductive health problems. So, we need a facilitator in order to solve these problems.
\end{abstract}

Keywords: knowledge, personal hygiene, case white discharge, young women.

\begin{abstract}
ABSTRAK
Penelitian ini adalah penelitian cross sectional. Penelitian ini dilakukan di Lembaga Pendidikan Islam Nurul Haromain "SMP Plus Fityani” Desa Ngroto Kecamatan Pujon Kabupaten Malang. Tujuan penelitian ini untuk mengetahui pengetahuan personal hygiene remaja putri dengan kasus keputihan. Peneliti menggunakan 50 responden dan semua memenuhi kriteria inklusi. Pengambilan sampel menggunakan total sampling. Variabel yang diteliti adalah karakteristik responden meliputi usia dan tingkat pendidikan. Sedangkan variabel pengetahuan personal hygiene meliputi cuci tangan sebelum menyentuh kelamin, cara yang benar membasuh vagina, penggunaan celana dalam, penggunaan panty liner. Untuk kasus keputihannya adalah keputihan yang dialami responden. Seluruh variabel diukur menggunakan kuesioner tertutup dan dianalisis menggunakan analisa deskriptif. Hasil penelitian karakteristik usia responden sebagian besar berusia 13 tahun. Hasil penelitian tentang pengetahuan personal hygiene sebagian besar remaja putri memiliki pengetahuan yang tidak baik sebesar 23 responden (46\%) tentang personal hygiene. Untuk kasus keputihan yang dialami sebagian besar keputihan yang dialami adalah keputihan yang tidak normal yaitu sebesar 27 responden (54\%). Pengetahuan tidak baik disebabkan keterbatasan akses informasi dan fasilitator di Lembaga Pendidikan tersebut. Jika dibiarkan maka akan menimbulkan masalah kesehatan reproduksi yang serius. Sehingga diperlukan fasilitator dalam rangka memecahkan masalah tersebut.
\end{abstract}

Kata kunci: pengetahuan, personal hygiene, kasus keputihan, remaja putri. 


\section{PENDAHULUAN}

Kesehatan reproduksi merupakan masalah yang serius sepanjang hidup manusia. Pemerintah sangat mendukung pemberian informasi, konseling dan sebagai bagian dari hak bereproduksi mereka untuk mendapatkan pelayanan kesehatan reproduksi yang seluasluasnya. Sasaran tujuan dari program kesehatan reproduksi di Indonesia adalah seluruh remaja (Depkes RI, 2001). Menurut WHO, sebagian besar komposisi penduduk dunia adalah remaja berusia $10-19$ tahun atau satu milyar dari enam milyar penduduk dunia (Elistiawaty, 2006).

Fase berkembang antara masa anak dengan masa dewasa adalah masa remaja (Potter dan Perry, 2006). Pada masa ini seorang remaja dorongan seksualnya akan meningkat dan akan selalu mencari informasi lebih banyak tentang seks. Remaja jaman sekarang lebih terbuka dan bebas sehingga mereka menerima tentang kehidupan seks bebas di luar pernikahan sementara pengetahuan tentang kesehatan reproduksi dan informasi berkaitan tentang kesehatan reproduksi yang mereka miliki sangatlah sedikit, baik di sekolah maupun di lingkungan keluarganya. Sebagian besar masyarakat Indonesia yang masih memegang tradisi menganggap tabu tentang hal-hal yang berhubungan dengan kesehatan reproduksi (Maulinda, 2010).

Remaja merupakan calon generasi penerus bangsa yang memiliki pengaruh besar terhadap segala tindakan yang mereka lakukan. Remaja juga merupakan kelompok masyarakat yang paling sering memiliki masalah mulai dari masalah sosial, perilaku hingga kesehatan reproduksi (BKKBN, 2006).

Keputihan adalah salah satu masalah kesehatan reproduksi remaja khususnya yang sering dikeluhkan oleh wanita. Masalah keputihan yang terjadi pada remaja perlu mendapatkan perhatian khusus. Jika keputihan pada saat remaja dibiarkan maka akan menimbulkan penyakit yang serius. Keputihan adalah sesuatu hal yang wajar. Keputihan terjadi menjelang saat menstruasi. Keputihan masih dalam batas normal selama berwarna bening atau jernih, selama tidak berbau, tidak terasa gatal dan dalam jumlah yang tidak berlebihan. Bila cairan berubah menjadi warna kekuningan, berbau dan disertai gatal maka telah menjadi keputihan yang tidak normal (Herdalena, 2003).

Wanita di Eropa yang mengalami keputihan hanya $25 \%$ saja. Angka ini sangat berbeda tajam dengan yang terjadi di Indonesia, di mana persentase wanita Indonesia yang pernah mengalami keputihan tersebut cukup besar. Sekitar $75 \%$ dari 118 juta wanita yang berada di Indonesia pernah mengalami kejadian keputihan dalam hidupnya, paling tidak satu kali. Di Indonesia wanita yang mengalami keputihan disebabkan keadaan iklim di Indonesia yang lembab, berbeda dengan iklim kering yang ada di eropa sehingga wanita di Eropa tidak mudah terinfeksi jamur yang menjadi penyebab keputihan (Hurlock, 2007).

Data WHO (2007) menyebutkan, angka prevalensi tahun 2006, 25\% - 50\% candidiasis, $20 \%-40 \%$ bacterial vaginosis dan $5 \%-15 \%$ trichomoniasis. Penyebab utama keputihan patologis ialah infeksi (jamur, kuman, parasit dan virus). Keputihan patologis dapat juga disebabkan karena kurangnya perawatan remaja putri terhadap alat genetalia seperti mencuci vagina dengan air yang tergenang di ember, menggunakan pembilas secara berlebihan, memakai celana dengan bahan yang tidak menyerap keringat, jarang mengganti celana dalam, dan tak sering mengganti pembalut saat menstruasi (Aulia, 2012).

Banyak wanita di Indonesia yang tidak tahu tentang keputihan sehingga mereka menganggap keputihan sebagai hal yang sudah biasa dan sepele, di samping itu rasa malu ketika para wanita/remaja mengalami keputihan kerap membuat wanita/remaja tersebut enggan berkonsultasi ke dokter. Padahal keputihan tidak bisa dianggap sepele, karena akibat dari keputihan ini sangat fatal bila lambat ditangani tidak hanya bisa mengakibatkan kemandulan dan hamil di luar kandungan. Keputihan juga bisa merupakan gejala awal dari kanker leher rahim (kanker serviks) yang bisa berujung pada kematian kalau tidak dikonsultasikan pada petugas kesehatan sejak dini (Sutarno, 2003).

Setiap tahunnya ada 8000 perempuan di Indonesia meninggal dikarenakan menderita penyakit kanker serviks. Fakta yang muncul 
cukup menakutkan. Ini berarti seorang perempuan di Indonesia hampir setiap jam meninggal dunia karena terkena penyakit kanker serviks. Usia produktif wanita 30-50 tahun sering kali mudah terserang dan bisa membunuh wanita penderita kanker serviks, namun tanda dan gejala tersebut dapat timbul pada wanita dengan usia yang lebih muda dari usia produktif (Laila, 2008).

Menjaga kesehatan organ reproduksi berawal dari menjaga kebersihan diri, termasuk kebersihan vagina yang bertujuan agar vagina tetap bersih, normal, sehat dan terhindar dari kemungkinan muncul adanya penyakit termasuk keputihan. Adapun cara yang dapat dilakukan untuk perawatan pribadi terhadap vagina adalah: membersihkan vagina dengan cara membasuh bagian antara bibir vagina secara hati - hati dan perlahan, cara membasuh vagina yang benar dari arah depan ke belakang, hindari penggunaan pengharum dan sabun antiseptic secara terus menerus, karena dapat merusak keseimbangan flora normal dalam vagina, gantilah celana dalam 2 sampai 3 kali sehari dan menggunakan celana dalam yang bersih serta terbuat dari bahan katun. Mencuci tangan sebelum menyentuh vagina, jangan menggunakan handuk milik orang lain yang digunakan untuk mengeringkan vagina, cukurlah rambut vagina setidaknya 7 hari sekali dan maksimal 40 hari sekali untuk mengurangi kelembapan di dalam vagina, pada saat haid gunakan pembalut yang nyaman, dan berbahan lembut, apabila menggunakan closet umum siramlah terlebih dahulu tempat dudukan closet dan keringkan menggunakan tisu toilet (Wulandari, 2011).

Pondok pesantren merupakan lembaga pendidikan Islam tertua yang merupakan produk budaya Indonesia. Pondok pesantren merupakan tempat pendidikan dan pengajaran yang menekankan pada pelajaran agama Islam dan didukung oleh asrama sebagai tempat tinggal santri. Pondok pesantren memiliki tiga kategori yaitu tradisional, modern dan perpaduan.

Remaja berinteraksi selama 24 jam di pondok pesantren dengan komunitas teman usia sebaya. Pondok pesantren memiliki ciri hidup sederhana, menanamkan kemandirian, adanya riyadloh, disiplin dan tolong menolong (Peni C, dkk. 2010). Namun masalah kesehatan di pondok pesantren masih memerlukan perhatian khusus dari berbagai pihak yang terkait. Terutama dalam akses pelayanan kesehatan, perilaku sehat maupun kesehatan lingkungan (Prateek S, dkk, 2011). Berdasarkan penelitian Isa Ma'ruf (2005), pada 6 pondok pesantren yang ada di Jawa Timur memberikan hasil bahwa sebesar $64,20 \%$ santri menderita penyakit scabies, sedangkan $73,70 \%$ santri memiliki hygiene perorangan yang buruk, perilaku sering memakai baju atau handuk secara bergantian dengan teman-temannya dan masih banyak ditemui sanitasi lingkungan pondok pesantren kurang baik, sehingga halhal tersebut akan sangat berpengaruh bagi kesehatan reproduksi remaja yang berada di pondok pesantren tersebut (Ayalew T, 2008). Ainur Rofieq melakukan penelitian di pondok pesantren yang berada di Kabupaten Malang didapatkan bahwa pengetahuan dan perilaku kesehatan remaja di pondok pesantren masih rendah. Hasilnya menunjukkan bahwa remaja putri memiliki pengetahuan yang buruk tentang cara menjaga personal hygiene serta remaja putri tidak melakukan olahraga, cara mandi yang harus mengantri, bergabung dengan banyak teman dan terkadang mandi di sungai (Malleshappa $\mathrm{K}$, 2011).

Berdasarkan studi pendahuluan yang telah dilakukan di Lembaga Pendidikan Islam "SMP Plus Fityani" Desa Ngroto Kecamatan Pujon Kabupaten Malang menyatakan bahwa semua remaja putri tinggal di asrama yang telah disediakan. Semua remaja putri di tempat tersebut sudah mengalami menstruasi dan pernah mengalami keputihan bahkan sebagian besar sering mengalami keputihan.

Tujuan dari penelitian ini adalah untuk mendeskripsikan bagaimana pengetahuan remaja putri tentang personal hygiene pada kasus keputihan.

\section{METODE PENELITIAN}

Dalam penelitian ini menggunakan rancangan cross sectional, variabel pada rancangan tersebut diamati dan diukur dalam waktu yang sama saat penelitian ini berlangsung. Penelitian ini menggunakan Pendekatan deskriptif. Penelitian dilakukan di Lembaga Pendidikan Islam Nurul 
Haromain "SMP Plus Fityani" Desa Ngroto Kecamatan Pujon Kabupaten Malang pada bulan November 2015.

Populasi pada penelitian ini adalah seluruh siswi "SMP Plus Fityani" yang tinggal di Pondok Pesantren Nurul Haromain Desa Ngroto Kecamatan Pujon Kabupaten Malang yang masuk dalam kriteria inklusi. Menurut kriteria inklusi responden memenuhi kriteria inklusi sebanyak 50 responden. Kriteria inklusinya yaitu: 1) bersedia menjadi responden, 2) berusia 13-15 tahun, c) sudah menstruasi, d) hadir pada saat penelitian, e) dapat membaca, menulis, dan memahami informasi yang diberikan baik melalui verbal maupun lisan. Dalam penelitian ini mengkaji seluruh anggota populasi, jadi tidak dilakukan pengambilan sampel dalam penelitian ini.

Variabel yang diteliti adalah: pengetahuan remaja putri tentang personal hygiene yang meliputi pengetahuan tentang sebelum membasuh alat kelamin harus cuci tangan dengan sabun terlebih dahulu, pengetahuan tentang cara membasuh vagina yang benar, pengetahuan tentang pemakaian celana dalam, dan pengetahuan tentang penggunaan pantyliner. Dalam penelitian ini data yang digunakan adalah data primer yang diperoleh dengan menggunakan kuesioner. Kuesioner diisi oleh responden. Analisis data dilakukan secara deskriptif dengan disajikan dalam bentuk tabel distribusi frekuensi.

\section{HASIL PENELITIAN}

\section{Karakteristik Umum Responden}

Tabel 1. Distribusi Responden berdasarkan Usia

\begin{tabular}{lcc}
\hline Usia & Jumlah & Persentasi (\%) \\
\hline 13 tahun & 24 & 48 \\
14 tahun & 23 & 46 \\
15 tahun & 3 & 6 \\
\hline Total & $\mathbf{5 0}$ & $\mathbf{1 0 0}$ \\
\hline
\end{tabular}

Hasil penelitian distribusi karakteristik responden berdasarkan usia diuraikan pada tabel 1 .
Berdasarkan tabel di atas diketahui bahwa responden yang paling banyak pada usia 13 tahun yaitu sebanyak 24 responden (48\%). Terdapat 3 responden $(6 \%)$ yang berumur 15 tahun

\section{Pengetahuan Personal Hygiene}

Hasil penelitian distribusi pengetahuan personal hygiene remaja putri pada kasus keputihan diuraikan pada tabel 2 .

Tabel 2. Pengetahuan Personal Hygiene Remaja Putri pada Kasus Keputihan

\begin{tabular}{lcc}
\hline Pengetahuan & Jumlah & \% \\
\hline Baik & 0 & 0 \\
Cukup & 14 & 28 \\
Kurang Baik & 13 & 26 \\
Tidak Baik & 23 & 46 \\
\hline Total & $\mathbf{5 0}$ & $\mathbf{1 0 0}$ \\
\hline
\end{tabular}

Dari tabel di atas dapat diketahui bahwa sebagian besar responden memiliki pengetahuan yang tidak baik sebesar 23 responden $(46 \%)$ tentang personal hygiene. Tidak ada responden yang memiliki pengetahuan baik tentang personal hygiene. Sedangkan untuk yang memiliki pengetahuan cukup sebanyak 14 responden (28\%) dan kurang baik 13 responden $(26 \%)$.

\section{Kasus Keputihan Disertai Gatal}

Tabel 3. Keputihan yang Dialami Responden Disertai Rasa Gatal pada Daerah Keperempuanan

\begin{tabular}{lcc}
\hline & Jumlah & $\mathbf{\%}$ \\
\hline Tidak & 11 & 22 \\
Ya & 39 & 78 \\
\hline Total & $\mathbf{5 0}$ & $\mathbf{1 0 0}$ \\
\hline
\end{tabular}

Hasil penelitian distribusi keputihan yang dialami responden disertai rasa gatal pada daerah keperempuanan akan diuraikan pada tabel 3.

Berdasarkan tabel di atas dapat diketahui bahwa sebagian besar responden mengalami keputihan yang disertai rasa gatal pada daerah keperempuanan yaitu sebesar 39 responden 
Tabel 4. Keputihan yang Dialami Disertai Bau Tidak Sedap pada Daerah Keperempuanan

\begin{tabular}{lcc}
\hline & Jumlah & \% \\
\hline Tidak & 19 & 38 \\
Ya & 31 & 62 \\
\hline Total & $\mathbf{5 0}$ & $\mathbf{1 0 0}$ \\
\hline
\end{tabular}

Tabel 5. Warna Keputihan yang Dialami

\begin{tabular}{lcc}
\hline & Jumlah & $\mathbf{\%}$ \\
\hline Putih & 9 & 18 \\
Bening & 13 & 26 \\
Putih kekuningan & 28 & 56 \\
\hline Total & $\mathbf{5 0}$ & $\mathbf{1 0 0}$ \\
\hline
\end{tabular}

(78\%). Keputihan yang tidak disertai rasa gatal sebanyak 11 responden $(22 \%)$.

\section{Keputihan Disertai Bau}

Hasil penelitian distribusi keputihan yang dialami responden apakah disertai bau tidak sedap pada daerah keperempuanan diuraikan pada tabel 4.

Berdasarkan tabel di atas dapat diketahui bahwa sebagian besar responden mengalami keputihan yang disertai bau tidak sedap yaitu sebesar 31 responden (62\%). Sedangkan keputihan yang tidak disertai bau sebesar 19 responden $(38 \%)$.

\section{Warna Keputihan yang Dialami}

Hasil penelitian distribusi warna keputihan yang dialami responden diuraikan pada tabel 5.

Berdasarkan tabel di atas dapat diketahui bahwa sebagian besar warna keputihan yang dialami responden adalah putih kekuningan yaitu sebesar 28 responden (56\%), sedangkan keputihan yang dialami berwarna putih sebesar 9 responden (18\%) dan yang mengalami keputihan berwarna bening sebesar 13 responden $(26 \%)$.
Tabel 6. Analisis Kasus Keputihan pada Remaja Putri di Lembaga Pendidikan Islam Nurul Haromain "SMP Plus Fityani”

\begin{tabular}{lcc}
\hline Kasus Keputihan & Jumlah & $\mathbf{\%}$ \\
\hline Normal & 23 & 46 \\
Tidak Normal & 27 & 54 \\
\hline Total & $\mathbf{5 0}$ & $\mathbf{1 0 0}$ \\
\hline
\end{tabular}

Analisis Kasus Keputihan pada Remaja putri di Lembaga Pendidikan Islam Nurul Haromain "SMP Plus Fityani"

Berdasarkan tabel di atas dapat diketahui bahwa sebagian besar responden mengalami keputihan yang tidak normal yaitu sebesar 27 responden $(54 \%)$.

\section{PEMBAHASAN}

\section{Karakteristik Responden}

\section{Usia Responden}

Berdasarkan hasil penelitian diketahui bahwa sebagian besar responden berada pada usia 13 tahun. Usia 13 tahun termasuk masa remaja awal.

Pada tahun 2012, dari 43,3 juta jiwa remaja berusia 13-24 tahun di Indonesia berperilaku tidak sehat. Hal ini berdasarkan data statistik Indonesia. Remaja putri Indonesia dari 23 juta jiwa berusia $13-24$, tahun $83,3 \%$ pernah berhubungan seksual, yang merupakan salah satu penyebab terjadinya keputihan (Depkes RI, 2011) Faktor usia turut berperan dalam seseorang memperoleh pengetahuan. Remaja usia 12-14 tahun merupakan masa remaja awal. Pengetahuan yang rendah pada responden 13 tahun yaitu sebesar $48 \%$, dibandingkan dengan usia 14 tahun dan 15 tahun dapat disebabkan beberapa faktor. Faktor kematangan kognitif yang masih kurang dibandingkan dengan masa remaja akhir. Informasi yang didapatkan remaja mungkin berbeda dengan masa remaja akhir. 
Informasi yang didapatkan remaja mungkin berbeda dengan informasi yang diperoleh remaja usia lainnya.

Semakin tinggi usia seseorang, makin berkembang pula daya tangkap dan daya pikir yang dimilikinya (Notoatmodjo, 2007). Kematangan kognitif dan psikologis juga akan semakin meningkat. Tetapi remaja usia 12-14 tahun merupakan periode remaja awal dengan pola pikir dan kematangan yang belum berkembang sempurna. Berbeda dengan saat remaja akhir (17-21 tahun) yang mencapai kematangan secara kognitif dan memperoleh pengalaman hidup tentang yang baik dan buruk, di mana mereka mengembangkan aturan moral mereka sendiri.

\section{Pengetahuan Personal Hygiene Remaja Putri}

Berdasarkan hasil penelitian diperoleh bahwa sebagian besar responden mempunyai pengetahuan yang tidak baik tentang Personal Hygiene yaitu sebanyak 23 responden (46\%) dan tidak ada yang memiliki pengetahuan yang baik. Menurut (Notoatmodjo, 2007), pengetahuan adalah hasil dari tahu dan terjadi setelah seseorang melakukan penglihatan terhadap suatu benda tertentu. Dalam Kamus Besar Bahasa Indonesia (2005), pengetahuan yaitu suatu hal yang dapat diketahui serta berkaitan dengan proses belajar mengajar. Kegiatan belajar dipengaruhi banyak yang berasal dari faktor dalam, seperti motivasi dan faktor luar berupa sarana informasi yang tersedia, serta keadaan sosial budaya (Budiman dan Riyanto, Agus., 2013).

Pengetahuan seseorang dapat dipengaruhi oleh banyak hal, salah satu yang memengaruhi yaitu pendidikan. Pengetahuan sangat berkaitan dan berhubungan dengan pendidikan, yang artinya apabila seseorang memiliki pendidikan yang tinggi maka pengetahuannya pun ikut tinggi. Menurut Andira (2010), faktor-faktor yang dapat berpengaruh terhadap personal hygiene yaitu: Body Image, gambaran individu terhadap dirinya sendiri sangat memengaruhi kebersihan diri misalnya karena adanya perubahan fisik sehingga individu tidak peduli terhadap kebersihan terhadap dirinya. Praktik sosial, pada masa anak - anak yang tidak mandiri dalam menjaga kebersihan diri, sehingga personal hygiene dapat berubah. Status sosial ekonomi dan personal hygiene memerlukan alat dan bahan seperti sabun, alat mandi yang semuanya memerlukan uang untuk menyediakannya. Pengetahuan personal hygiene sangat penting karena pengetahuan yang baik dapat meningkatkan derajat kesehatan. Budaya, pada sebagian masyarakat tertentu mengatakan bahwa jika seorang individu mengalami sakit maka tidak boleh dimandikan. Kebiasaan seseorang, terdapat kebiasaan seseorang individu dalam penggunaan produk tertentu dalam perawatan dirinya. Kondisi fisik, pada keadaan seorang individu yang sedang sakit tertentu memiliki kesanggupan untuk merawat dirinya berkurang dan perlu untuk mendapatkan bantuan melakukannya.

Faisal (2009) dalam penelitiannya mengatakan bahwa sebenarnya, membahas masalah pendidikan kesehatan reproduksi di kalangan pondok pesantren tentu bukan hal yang asing lagi. Sebab, tidak sedikit ayat maupun hadist serta pemikiran ulama yang berhubungan dengan hal tersebut dipelajari dalam kitab-kitab kuning khususnya kitab kitab fiqih, yang menjadi basis keilmuan pondok pesantren. Ilmu fiqih memberikan bimbingan, petunjuk tuntunan, pengetahuan dan nilai bagaimana seorang muslim harus bersikap dan mengambil keputusan berkaitan dengan kesehatan reproduksinya.

Model pemberian informasi tentang personal hygiene yang tepat yaitu dengan cara dijelaskan secara langsung dan disertakan dengan gambar, hal ini dilakukan agar informasi yang diberikan dapat diterima dengan baik oleh remaja putri di pondok pesantren. Karena remaja putri mengatakan bahwa jika hanya sekedar penjelasan saja tanpa ada gambar yang diperlihatkan, santri/ santriwati hanya akan membayangkan saja.

Masalah kebutuhan remaja putri tentang pengetahuan Personal hygiene ternyata tidak sesuai dengan sumber informasi yang tersedia di pondok pesantren. Berdasarkan hasil wawancara bahwa sumber informasi yang tersedia di pondok pesantren hanyalah dari guru fiqih. Sedangkan yang disinggung hanyalah menghubungkan antara ilmu agama dan ilmu kesehatan. padahal banyak informasi yang dibutuhkan oleh remaja putri di pondok pesantren tetapi tidak tersedia di pondok pesantren seperti pengetahuan personal 
hygiene, masalah penyakit reproduksi, cara pencegahan dan pengobatan.

Menurut Tanuwidjaya (2002), tingkat pengetahuan remaja berpengaruh terhadap kesehatannya yang dimiliki oleh remaja jika terjadinya kelainan atau gangguan kesehatan pada remaja, maka dapat segera diatasi secepat mungkin, jadi tingkat pengetahuan sangatlah erat kaitannya.

\section{Kasus Keputihan Remaja Putri}

Keputihan (Leukorhea/vaginal discharge) adalah keluarnya secret/cairan dari vagina. cairan tersebut dapat bermacam - macam jenis dalam warna dan bau. Keputihan dapat merupakan suatu keadaan yang normal (fisiologis) atau sebagai tanda dari adanya penyakit (patologis). Keputihan yang normal biasanya tidak berwarna/ bening, tidak berbau, tidak berlebihan dan tidak menimbulkan keluhan. Sedangkan keputihan yang tidak normal biasanya berwarna kuning/ hijau/keabu-abuan, berbau amis/busuk, jumlahnya banyak dan menimbulkan keluhan seperti gatal dan rasa terbakar pada daerah intim (Agustini, 2007).

Berdasarkan distribusi frekuensi menunjukkan bahwa sebagian besar responden mengalami keputihan yang disertai rasa gatal dan berbau. Keputihan bisa terjadi disebabkan karena banyak hal, Misalnya disebabkan karena adanya benda asing yang masuk pada vagina, jika terjadi luka pada vagina, bakteri dari lingkungan sekitar yang kotor, air yang tidak bersih, penggunaan tampon atau panty liner secara terus menerus. Hal tersebut berpotensi membawa bakteri, virus, parasit dan jamur. Dalam vagina wanita terdapat berbagai bakteri yang bersarang, 95\% yang ada di dalamnya adalah bakteri lactobacillus dan selebihnya merupakan bakteri yang merugikan (bakteri yang bisa menyebabkan penyakit). Dalam kondisi lingkungan vagina yang berada dalam kondisi seimbang, bakteri patogen yang ada didalamnya tidak akan bisa mengganggu. Menjaga derajat keasaman $(\mathrm{pH})$ agar selalu tetap pada level normal merupakan peran penting dari bakteri dalam flora vaginal. Dengan tingkat keasaman yang ada tersebut, bakteri lactobacillus akan tumbuh subur dan bakteri patogen yang ada didalamnya akan mati. Namun, pada keadaan tertentu kadar $\mathrm{pH}$ bisa berubah menjadi lebih tinggi ataupun lebih rendah dari kadar $\mathrm{pH}$ normal. Jika $\mathrm{pH}$ yang terdapat pada vagina naik menjadi lebih tinggi dari 4,2 (kurang asam), maka jamur akan bisa tumbuh dan berkembang. Akibatnya, bakteri lactobacillus akan kalah dari bakteri patogen (Grer, 2003).

Jika dilihat dari angka kejadian keputihan pada remaja putri dari 50 responden semua remaja putri pernah mengalami keputihan. Keputihan dapat terjadi sebelum dan setelah menstruasi. Pada saat masa subur merupakan hal yang normal dan hampir sebagian besar perempuan di Indonesia pernah mengalami keputihan. Selain itu Indonesia adalah negara yang beriklim tropis sehingga berpotensi mengalami keputihan (Nurul, 2001).

Hasil ini menunjukkan bahwa kejadian keputihan pada remaja putri masih cukup tinggi. Hal ini dapat diartikan bahwa sangat penting untuk dilakukan penanganan terhadap keputihan yang dialami oleh remaja putri. Terdapat 2 jenis keputihan yang dialami remaja putri yaitu keputihan normal dan keputihan abnormal. Jenis keputihan yang paling banyak dialami oleh remaja putri adalah keputihan tidak normal sebanyak 27 responden (54\%).

Hasil penelitian ini mendukung penelitian yang dilakukan oleh Astuti dkk, (2008), dengan hasil bahwa ada hubungan antara pengetahuan vulva hygiene dengan kejadian keputihan pada remaja putri kelas IX di SMP 2 Ungaran. Penelitian Maghfiroh, (2010) dengan hasil terdapat hubungan yang bermakna yaitu antara pengetahuan personal hygiene dengan penanganan keputihan pada siswi Pondok Pesantren Darul Hasanah Kalikondang Demak.

Kesamaan hasil penelitian ini menyimpulkan bahwa pengetahuan mempunyai kontribusi penting dalam pembentukan pemeliharaan organ reproduksi yang selanjutnya memengaruhi kejadian keputihan.

Meskipun keputihan merupakan penyakit yang sederhana, namun dalam kenyataannya keputihan merupakan penyakit yang sulit untuk disembuhkan. Populasi perempuan dan hampir semua umur berisiko terserang penyakit keputihan ini hampir 50\%. (Putu, 2009). 
Hasil dari penelitian ini menyimpulkan bahwa pengetahuan tentang kesehatan reproduksi berpengaruh terhadap kejadian keputihan. Pengetahuan yang dimiliki remaja putri memengaruhi pola pikir yang akhirnya akan meningkatkan kesadaran untuk menjaga kesehatan reproduksi sehingga kejadian keputihan dapat dihindari. Hal ini berimplikasi bahwa sangat penting untuk memberikan pengetahuan kesehatan reproduksi pada remaja yang dapat dilakukan melalui kegiatan pendidikan kesehatan, penyuluhan maupun konseling tentang kesehatan reproduksi pada remaja putri. Orang tua juga memiliki peran yang penting apalagi yang mempunyai anak perempuan maka perlu pendidikan serta pengetahuan tentang kesehatan reproduksi.

\section{SIMPULAN DAN SARAN}

\section{Simpulan}

Dari hasil pembahasan dan analisis data sehingga dapat disimpulkan bahwa karakteristik usia remaja putri di Lembaga Pendidikan Islam Nurul Haromain "SMP Plus Fityani" desa Ngroto Kecamatan Pujon Kabupaten Malang sebagian besar berusia 13 tahun. Untuk pengetahuan tentang personal hygiene pada remaja putri di Lembaga Pendidikan Islam Nurul Haromain "SMP Plus Fityani" Desa Ngroto Kecamatan Pujon Kabupaten Malang memiliki pengetahuan yang tidak baik tentang personal hygiene. Sedangkan untuk kasus keputihan yang dialami remaja putri di Lembaga Pendidikan Islam Nurul Haromain "SMP Plus Fityani” Desa Ngroto Kecamatan Pujon Kabupaten Malang sebagian besar termasuk keputihan yang tidak normal.

\section{Saran}

Meningkatkan penyuluhan dan informasi mengenai pentingnya menjaga kesehatan organ reproduksi terutama organ genetalia eksterna agar terhindar dari keputihan, karena hasil dari penelitian menunjukkan bahwa pengetahuan yang mereka miliki sebagian besar tidak baik sehingga keputihan yang mereka alami sebagian besar keputihan yang tidak normal. Dalam hal ini Unit Kesehatan Sekolah (UKS) juga berperan penting. Bagi remaja putri, mendapatkan ilmu atau suatu informasi yang baru jangan hanya sebatas tahu saja, tapi juga harus dipraktikkan hal yang baiknya, dalam hal ini kebersihan organ genetalia untuk mencegah terjadinya keputihan.

\section{DAFTAR PUSTAKA}

Agus, R. Budiman. 2013 Kapita Selekta Pengetahuan dan Sikap dalam Penelitian Kesehatan. Salemba Medika: Jakarta

Agustini. 2007. Si Putih Yang Menganggu, Online. Available: http: //astaqauliyah.com. Diakses 13 januari 2016

Andira, D. 2010. Seluk beluk kesehatan reproduksi wanita. Yogyakarta: A. PLUS BOOK

Astuti A.W.dkk 2008. Hubungan Perilaku Vulva Hygiene dengan kejadian keputihan pada remaja putri di kelas ix SMP Unggaran Semaran Yogyakarta. Stikes Aisiyah Yogyakarta.

Aulia.2012. Serangan penyakit-penyakit khas wanita paling sering terjadi. Yogyakarta, buku biru

BKKBN. 2006. Lomba Karya Tulis Remaja. Available online: http: //www.bkkbn.go.id/ Webs/DetailRubrik.aspx?MyID-2255.c02 Desember 2012

Depkes, RI. 2009. Kesehatan Reproduksi. UNFPA. Jakarta

Depkes RI. 2001. Program Kesehatan Reproduksi Dan Pelayanan Integrative Ditingkat Pelayanan Dasar. Jakarta: Depkes

Depkes, RI. 2011 Survey Demografi Kesehatan Indonesia tahun 2011 Depkes RI Survey

Elistiawaty. 2006. Internet. Wanita RI Alami Keputihan. http: //www.detiknews,com diakses tanggal 18 Januari 2016 jam 13.00

Faisal. 2009. Implementasi Pendidikan Kesehatan Reproduksi di Pondok Pesantren Miftahussada Mijen Semarang. Skripsi IAIN Walisongo Semarang.

Greer, IA., Cameron I T., Mangowan B. 2003. Vaginal Discharge. Problem based Obstetrics and Gynecology. London. Churchill Livingstone: 37-90

Herdalena, N. 2003. Pengetahuan dan Perilaku Seksual Remsja. Bening 2003. Vol IV

Hurlock E .2007.Psikologi Perkembangan Suatu Pendekatan Sepanjang Tentang Kehidupan. Jakarta ; Erlangga 
Ilmiawati, H. 2016 Perilaku Personal Hygiene Pada Kasus Keputihan Remaja Putri di Lembaga Pendidikan Islam Nurul Haromain "SMP Plus Fityani"Desa Ngroto Kecamatan Pujon Kabupaten Malang. Universitas Airlangga, Surabaya 2016

Laila. 2008. Skrining Kanker Serviks dengan Metode Skrining Alternatif: IVA. Cermin dunia Kedokteran, 133: 22-5

Maghfiroh, K. 2010. Hubungan Pengetahuan tentang personal hygiene dengan penanganan keputihan pada siswi pondok pesantren Darul Hasanah Kali Kondang Demak tahun 2010 Universitas Muhammadiyah Semarang.

Maulinda. 2010. Hubungan Pengetahuan dengan Sikap terhadap Pendidikan Kesehatan Reproduksi Remaja di SMPN 1 Margahayu. Skripsi Universitas Padjajaran Bandung

Notoatmodjo, S. 2007. Ilmu Kesehatan Masyarakat, Prinsip-prinsip Dasar, Jakarta: Rineka Cipta

Nurul. 2001. Infeksi Saluran Reproduksi (ISR) pada perempuan Indonesia. Depok: Pusat Komunikasi Kesehatan Perspektif Gender Bekerjasama dengan Ford Foundation.
Peni C, Kristyan N, Woro O, Perbedaan kadar $\mathrm{Hb}$ sebelum dan sesudah pemberian Fe pada santri putri di pondok pesantren AL Hidayah Kab.Grobongan. Unnes 2010

Potter, Patricia A. Dan Anne Griffin Perry. 2006. Buku Ajar Fundamental KeperawatanKonsep, Proses, dan Praktik.Edisi 4, Volume 2. Jakarta: EGC.

Prateek S, Saurabh R, Shrivastava. Cross Sectional Study Of Knowledge and Practice about Reproductive Health Among Female Adolescents in Urban Slum of Mumbai, journal of family and reproduction. 2011 5(4) $117-124$

Putu. 2009. Prevalensi Kejadian Keputihan. http: //www.ziddu.com/download/5028081/ atPrevalensi-kejadian.keputihan.zip diakses tanggal 30 januari 2016

Sutarno. 2003. Deteksi Dini dan Pencegahan Keputihan pada Wanita. FKM Undip: Semarang

Tanuwidjaya, S. 2003. Konsep Umum Tumbuh dan Kembang. Jakarta: EGC

Wulandari, A. 2011. Cara Jitu Mengatasi Nyeri Haid. Yogyakarta: ANDI 